\title{
MATERIALIST HISTORY OF IDEAS AND STUDY OF ARCHITECTURE AND URBANISM: THE CASE OF MARTIN JAY ${ }^{1}$
}

\section{A B S T R A C T}

History of ideas is a sub-discipline of history that deals with description and interpretation of creative work of thinkers and artists of the past. Martin Jay, as a central aspect of his theoretical work points out two Marxist thesis. 1. Ideas have, as products of intellectual labor, their own material foundation: this means that social reality is determined by those products as much as by economy - in that way, materialist history of ideas is constituted on the shift from the analysis of the economy (base) to the analysis of culture (superstructure). 2. Ideas are related to social practices: ideas within a society are not separate from material reality, but they actively shape social relations, i.e. there is a link between intellectual labor and political conditions of life within a given historical society. The paper examines the connection that Jay established between the history of ideas and the history of architecture and urbanism. 
Right at the outset of my presentation, I would like to emphasize that I do not consider myself an expert in the domain of architectural theory; in fact, the work I present today is the first text I have ever written on the topic of architecture. My proper field of expertise concerns the relationship between art theory, especially (post-)Marxist art theory, and the neo-avant-garde and post-avant-garde art practices of the latter half of the $20^{\text {th }}$ century. In my book, Utopian Spaces of Art and Theory after 1960 (published in 2009), I tried to encompass that set of problems and advanced the following claim: there is no art that is not, on some level, theoretical; quite to the contrary, every art practice is shaped according to a certain theoretical system that belongs to wider, often conflicting cultural and social processes. Therefore, in my theoretical work, I have often engaged not in art-historical analyses of concrete works or phenomena of art, but rather, in the surrounding theoretical narratives (philosophic-aesthetic systems, theoretical platforms), which constructed and are still constructing the political history of the $20^{\text {th }}$-century art. Thus, in my work as a theorist and historian of art, I have often assumed a meta-theoretical position and asserted the importance of addressing the theory of art theories. In other words, in my work, I have typically pursued not the history of art in the traditional sense, but rather, the history of the ideas affecting our conception of the objects and gestures that we bring together under the term 'art'.

What is the relationship between architecture and architectural theory? The French philosopher Louis Althusser once wrote that theory was important because it turned our irrational myths, obscure images, ideas, prejudices about the world and our place in it into rational concepts; these concepts are opposed to what Althusser signifies as ideology. By virtue of making that ideology visible, they command political weight; that is, theory, as a form of political practice is capable of shaping our lives, of laying the foundations for transcending our present conditions of life. It is almost banal to state that there is no more political form of art than architecture: architecture is nothing if not the practice of appropriating and performing, that is, regulating and shaping human space and living in it. ${ }^{2}$ Therefore, for anyone who deals with the relationship of art and politics by analyzing ideas, it is only logical to ask: what is the relationship between architecture and architectural theory, how to think the history of architecture as a political history of ideas, and how to analyze architecture as a political concept through a parallel analysis of theory as likewise a political concept? At least to hint at some answers to these questions, I would like to refer to a text by the American historian of ideas Martin Jay, published under the title of 'Scopic Regimes of Modernity' in Force Fields, a book that came 
out in 1993. In that essay, Jay directly broaches the issue of the relationship between ideas (theory) and architecture as a basically political relation. Still, in order to understand Jay's arguments in this brief text, it is necessary to make somewhat broader remarks concerning Jay's view of the history of ideas as a political history.

\section{I}

What does it mean when we say that ideas, or, more precisely, theory, carry political weight? For Jay, it means connecting to the materialist postulates of critical theory, according to which: 1) ideas, as products of material labor, have a material grounding; this means that these products shape social reality as much as the economy does and that materialist history of ideas is thus constituted at the transition charted by critical theory, between economic analysis (the base) and cultural analysis (the superstructure); 2) from that follows the idea about connecting theory and practice: in a given society, ideas are not separate from its material reality, but actively shape its social relations, i.e. there is a two-way loop between intellectual labor and political conditions of life in a historically given society.

Horkheimer and Adorno charted this turn from analyzing economy to analyzing ideas (scientific, philosophical, theoretical, artistic), that is, cultural superstructure, through their critique of the Second International era's vulgar economist Marxism. For theorists of the Frankfurt circle, ideas are never epiphenomenal, although, on the other hand, they are never quite autonomous either: ideas should be viewed as mediatized through the social totality and not as mere reflections of class interests. Therefore, the target of critical theory's attack is classical orthodox Marxism as much as formal logic, that is, positivism. This turn was predicated on a reinterpretation of Hegel's philosophy, that is, a turn from the positions of formal to those of speculative logic. While formal logic insists on an absolutely delimited, logically coherent and formalized, objective and a-historical theoretical meta-language, Hegel's speculative logic insists on the link between forms of thought (intellectual labor) and the historical conditions of social reality. Horkheimer's and Adorno's critique of the Enlightenment and the heritage of Cartesian rationality rest on these foundations: formal logic reduces reason and rationality to individual experience and insists on a transcendental detachment of reason from history. Logic is thus reduced to a series of tautologies that have no points of contact whatsoever with material conditions of human existence; at the same time, logical positivism keeps facts and values apart and thus contributes to the reproduction of the social status 
quo. By contrast, critical theory did chart an anti-metaphysical conception of rationality, whereby ideas stand in a dialectical relationship with history, that is, theory stands in a dialectical relationship with practice:

Horkheimer's stress on dialectics also extended to his understanding of logic. Although rejecting the extravagant ontological claims Hegel had made for his logical categories, he agreed with the need for a substantive, rather than merely formal, logic. In Dämmerung Horkheimer wrote: 'Logic is not independent of content. In face of the reality that what is inexpensive for the favored part of humanity remains unattainable for the others, nonpartisan logic would be as nonpartisan as a book of laws that is the same for all'. Formalism, characteristic of bourgeois law (the ideal of the Rechtsstaat, which means judicial universality without relating the law to its political origins), bourgeois morality (the categorical imperative), and bourgeois logic, had once been progressive, but it now served only to perpetuate the status quo. True logic, as well as true rationalism, must go beyond form to include substantive elements as well.

$[\ldots]$

What made Horkheimer's stress on reason so problematical was his equally strong anti-metaphysical bias. Reality had to be judged by the "tribunal of reason", but reason was not to be taken as a transcendental ideal, existing outside history. ${ }^{3}$

Therefore, the core starting point of Jay's history of ideas is deeply rooted in the Marxist tradition: according to Jay, ideas, products of intellectual labor, reflect the material conditions of the socio-historical context in which they emerge, but those same ideas are capable of shaping (in emancipatory, even utopian terms) and changing that same social context. That thesis may be identified already in Marx's classical positions on ideology, ${ }^{4}$ whereas the Frankfurt School developed it through their postulates relating to praxis, i.e. by combining theory and politics. Classical theory insists on pure, supposedly 'disinterested', 'objective' knowledge, privileged over practice and social action. For the Frankfurt School, disinterested knowledge is impossible, especially in a society like the bourgeois, where individuals are not autonomous; for Horkheimer, an intellectual is part of the social object $\mathrm{s} / \mathrm{he}$ examines and cannot avoid participating in social heteronomy. Critical theory thus rejects the idea of the 'free-floating' intellectual and the conception of 'objective' knowledge, striving for a theory that might determine social change:

In the present society, then, it would be a mistake to see intellectuals as freischwebende (free-floating), to use the term Manheim had taken 
from Alfred Weber and popularized it. The ideal of a 'free-floating' intellectual above the fray was a formalistic illusion, which should be discarded.

$[\ldots]$

Dialectical materialism, Horkheimer argued, also had a theory of verification based on practical, historical testing: 'truth is a moment in correct praxis; he who identifies it with success leaps over history and becomes an apologist for the dominant reality'. 'Correct praxis' is the key phrase here, indicating once again the importance in the Institute's thinking of theory as a guide to action $[\ldots]^{5}$

Thus Jay finds reasons for pursuing the history of ideas as a discipline in the postulates of the Frankfurt School: the history of ideas, as well as both theoretical and artistic, that is, intellectual labor in general, carry a potential for social emancipation. As Lloyd Kramer asserts, theory is capable of reexamining the ruling social, that is, ideological prejudices: when there is a lack of historical knowledge in a given society, its historians of ideas turn into critical thinkers who point to the forgotten genesis of certain ideas and their influence on commonsense (ideological) prejudices at that particular social moment. ${ }^{6}$ In other words, historical knowledge re-examines personal experience and 'spontaneity' of cultural prejudices, which form the basis of political ideologies. Theory thus assumes a central position in articulating the political debate about a just society: theory is a place of reflexive self-distancing from the 'spontaneous' ideology of the dominant political context. Theory initiates political practice, but at the same time, maintains a self-reflexive status in relation to that same practice; rational self-reflection and self-criticism are two conditions for social emancipation. In Jay's system, the humanities occupy a central position in reflecting on the conditions for the development of a democratic community; in that regard, Jay insists on the Enlightened, modern idea of intellectual labor as a process of rational communication: a rational analysis of ideas, intellectual and theoretical concepts is the basic task that every contemporary intellectual should pursue.

From all the foregoing, one may draw the following conclusion: the classic modernist separation of art 'practice' from art theory proves to be untenable. For historians of ideas, ideas actively shape reality, so one may say that there is interdependence, a two-way loop between, theoretical-philosophical platforms on the one hand and, on the other, art as such. In his book Downcast Eyes, Jay consistently pursues that approach, analyzing mechanisms whereby theory constructs the status of vision in Western rationalist and anti-rationalist 
traditions: Jay studies the nature of vision and claims that vision, that is, perception, has its 'natural' (therefore, physiological and psychological) grounding, but at the same time, in the spirit of materialist history of ideas, also argues that perception is culturally contingent and historically determined. ${ }^{7}$ In that regard, the position of an aesthetician or historian of art/architecture as a historian of ideas (as suggested in the introduction of this text) is metatheoretical, which means that the history of ideas offers history and theory of architectural theories within a certain historical context.

\section{I I}

What does it mean to apply these postulates of the material grounding of ideas and the interdependence of theory and 'practice' to the problems of architecture? In his essay mentioned above, Jay offers an analysis of the procedures of looking in Western culture, from the Renaissance to the present, and links those procedures with dominant intellectual lines in European thought. ${ }^{8}$ Only toward the end of the essay does Jay refer to architectural problems, that is, to the organization of cities in Western societies.

Jay isolates several dominant scopic regimes that have developed over the past 500 years or so: a) Cartesian perspectivism, which dominated the European space from the Renaissance until Neoclassicism, b) the narrative scopic regime, characteristic of the $17^{\text {th }}$-century Dutch art, and c) the Baroque scopic regime. Jay links these dominant 'forms' of European visual culture (which he recognizes above all in the domains of painting and city planning) with philosophical-intellectual traditions such as Alberti's Renaissance theory of space, Descartes's rationalism, as well as various humanist postulates in contemporary European philosophy (regarding Cartesian perspectivism), Bacon's empiricism (the narrative regime), and Leibnitz's and Pascal's philosophy and counter-Reformation mysticism (the Baroque).

In the regime of Cartesian perspectivism, the dominant ideas were those of a rational subject and literal representation of an 'objectively' given reality; relying on rationalism and assuming the existence of an objectively given world in its full materiality, as well as the possibility of cognizing and representing it literally and neutrally, without interest, led to the emergence of geometrical perspective and the postulates of the Italian Quattrocento, dominated by Brunelleschi's and Alberti's ideas of rational space: by means of precise calculations and reflection, three-dimensional space could be literally transposed to the two-dimensional surface of a painting. This kind of painting implies a 
static observer and fixed view, i.e. what British art historian Norman Bryson signifies under the term gaze: a viewing procedure that implies an almost biopolitical disciplining of the body - immobility, stillness, contemplation. ${ }^{9}$ This is a rational, de-eroticized gaze that negates desire and rejects narrativisation, that is, the discursive contingency of gazing. Cartesian perspectivism emerged in the tightest connection with the ideas of humanistic universalism: it was a transcendental conception of subjectivity that sought to comprehend the world in a neutral, rational way, from a-historical, disinterested positions. An alternative to Cartesian perspectivism was offered by the $17^{\text {th }}$-century Dutch art, as well as the parallel emergence of philosophical empiricism, based on description and narrativisation. This scopic regime insists not on the totality but rather on the fragmentariness of visual perception; Dutch paintings from the $17^{\text {th }}$ century present fragmentary excerpts of reality and not the totalizing view of the world characteristic of the Italian Renaissance; it is an art prone to allegorizing and metaphorising visual display. Finally, the third model of Western visual culture is the Baroque model - developed under the influence of counter-Reformation mysticism and not a rational, 'scientific' view of the world, the Baroque was a radical alternative to Cartesian perspectivism insisting not on perspective or geometry but on anamorphosis, deformation, not on reason, but on the sublime, mystical, on desire and eroticizing space. That is, in Jay's own words,

Baroque vision, Buci-Glucksmann also suggests, sought to represent the unrepresentable and, necessarily failing, produced the melancholy that Walter Benjamin in particular saw as characteristic of the baroque sensibility. As such, it was closer to what a long tradition of aesthetics called the sublime, in contrast to the beautiful, because of its yearning for a presence that can never be fulfilled. Indeed, desire, in its erotic as well as metaphysical forms, courses through the baroque scopic regime. The body returns to dethrone the disinterested gaze of the disincarnated Cartesian spectator. ${ }^{10}$

In the final two pages of that essay, Jay refers to the connection between these dominant scopic regimes and the architectural and city-planning organization of cities in Western culture. Cartesianism produced the rational conception of the city: the ideal of a geometric, isotropic, abstract, and uniform urbanized space, shaped in concentric circles radiating from a recognizable center. Jay's paradigmatic examples of the 'rational city' include the projects of Pope Sixtus V, Louis XIV, and the absolutist city-palaces at Versailles, Karlsruhe, and Mannheim, meant to highlight the power of the sovereign's gaze. Distant echoes of the Cartesian rational city Jay finds in Le Corbusier's projects as 
well as Lúcio Costa's monumental city-planning endeavors in Brasilia. Jay recognizes the narrative scopic regime in the anti-monumentality of cities like Delft, Haarlem, and Amsterdam: these cities 'seem less like visual incarnations of the disciplining state bent on controlling its citizenry through surveillance and more like comfortable sites of an active civil society'. ${ }^{11}$ These are cities that celebrate bourgeois privacy and emerge as a result of the accumulated wealth of the new bourgeois class and not the absolutist authority of a prince. Finally, the Baroque city insists on spectacle, on rejecting Cartesian geometric rationality; its typical embodiment is Bernini's Baroque Rome. The Baroque city addresses the senses and not reason, whereas architecture transforms into a theatrical space encompassing all public spectacles - from church processions to public executions. At the end, Jay analyses the fate of these scopic regimes today and their impact on the $20^{\text {th }}$-century city - linking the history of the gaze, the history of architecture and the history of ideas, Jay concludes that the Cartesian model was finally defeated at the end of the last century. The emergence of hermeneutics, pragmatism, and then structuralist and poststructuralist concepts dealt a deathblow to the conception of a disinterested, rational subject. The fate of Bacon's empiricism was no better, with its insistence on a positivistic grounding of human cognition. The dominant regime today, with its insistence on spectacle, the eroticization of the gaze, the bodily and the spectacular, is the Baroque regime - Jay assumes Adorno and Horkheimer's concept of 'cultural industry' and identifies in it elements of the spectacular Baroque production.

$\star \star \star$

Thus viewing the gaze in correlation with intellectual, that is, theoretical concepts from Western philosophy, Jay views not only the history of architecture from the Renaissance to the present, but also the entire history of the Western world through a cultural analysis of different ideas. The essence of Jay's approach is a basic 'de-ontologisation' of the history of art/architecture, by claiming the discursive nature of the gaze, which points to the transformation of art history from the study of sensuously presentable phenomena to art history as a discourse analysis. In other words, Jay expands the category of architecture itself: architecture is no longer viewed only as a material organization of space; rather, the architectural emerges in the intertwining of the social processes (material labor) and ideas (intellectual labor) that shape the scopic regimes discussed above. Architecture is a product not only of the economy or political power; it is not only the aesthetic form or practice of shaping the living space, but also a reflection of the ruling ideas and intellectual concepts of its 
time. This radically inverts the way we think architecture: architecture is not only labor in the domain of planning, designing, and constructing buildings and organizing space, it does not emerge only in the interstices between civil engineering, applied arts, industrial design, economics, and 'high art'. Architecture works with ideas and arises in the name of ideas. For Jay, ideas, intellectual, philosophical, and theoretical concepts carry political weight ideas reflect the material reality of a certain historical moment, but they are also capable of politically transfiguring that same material reality. According to Jay, that is precisely where architecture's political 'weight' lies.

That claim opens room for rethinking the social role of the architect; as already asserted, one of Jay's central concepts is that of the critical intellectual. Via that concept, Jay strives to reconstruct Habermas's concept of a rational public sphere, rejected by postmodern, post-structuralist theory as a totalizing and 'metaphysical' idea. Still, with his thesis on the critical intellectual, Jay departs from post-structuralist theorists, insisting, in Habermas's spirit, on the emancipatory idea of the modernist project. The figure of the critical intellectual entails theoretical and public acting:

Finally, Jay supports the traditional Enlightenment conception of intellectual labor as a process of rational communication. The intellectual must convince others by arguing for an idea rather than by compelling consent through social power or producing an irrational public spectacle. Rational analysis becomes for Jay the essential and difficult work that intellectuals should pursue: 'The neutral culture of critical discourse in which persuasive ideas come before personal authority and disembodied minds argue without reference to their corporeal ground may be a utopian fantasy in its purest form', Jay argues in one defense of rational argumentation, 'but it still provides a regulative ideal, which we abandon at our jeopardy'. ${ }^{12}$

In other words, the hard-won 'critical edge' of rationalism should be a guide for historians and critics of ideas, regardless of the theoretical school or camp they belong to in contemporary cultural debates. ${ }^{13}$ Rejecting the public sphere and insisting on the 'transgressiveness' of language instead of intersubjective nature of rational communication leads toward privatization of language; every language is public, therefore political action is possible only in the public sphere. There hardly exists a more 'public' art than architecture: in its spatial articulation of the public, architecture organizes forms of living on a bio-political level, that is, architecture is 'an ideological practice, because architectural production and consumption are material instruments and 
functional factors of the social and cultural, political and state-legal everyday reality of every historical and geographic society. Architecture is not a mimesis of social reality, but a basic instrument of constituting and performing social reality in its concreteness and universality'. ${ }^{14}$ In that respect, an architect is not only an artist, especially not in the modernist sense, that is, an author who constructs disinterested aesthetic forms, independent and neutral with regard to the historical, ideological, and political determinants of the social context. Still, an architect is not only a closely specialized expert either, working in the domain of designing everyday life structures, or city planning and articulating living space. An architect is so much more than that: $\mathrm{s} / \mathrm{he}$ is a critical intellectual working in the domain of ideas and intellectual concepts; therefore, s/he is (or ought to be) a political subject occupying a central position in debates about justice and a just society.

This text was presented at the conference "on Architecture" organized by Sustainable Urban Society Association at Serbian Academy of Sciences and Art in Belgrade, december 9th and 10th 2013. It was written within scientific project „Tradicija, modernizacija i nacionalni identitet u Srbiji i na Balkanu u procesu evropskih integracija“ (Tradition, modernization and national identity in Serbia and the Balkans in the EU integration process) (Reg. No. 179074), Center for Sociological Research, Faculty of Philosophy, Nis. Miško Šuvaković, Pojmovnik teorije umetnosti (A Lexicon of Art Theory; Belgrade: Orion Art, 2011), 92-93. Social Research, 1923-1950 (London: Heinemann, 1973), 55 and 63. 1970); Maynard Solomon, "General Introduction: Karl Marx and Friedrich Engels," in Marxism and Art: Essays Classic and Contemporary,ed. Maynard Solomon (Detroit: Wayne State University Press, 1974), 3-21; Terry Eagleton, Ideology: An Introduction (London and New York: Verso, 1991). 
Lloyd Kramer, "Martin Jay and the Dialectics of Intellectual History," in The Modernist Imagination: Intellectual History and Critical Theory, ed.Warren Breckman et al. (New York: Berghahn Books, 2011), xiii-xiv. Martin Jay, Downcast Eyes: The Denigration of Vision in Twentieth-century French Thought (Berkeley: University of California Press, 1993).

Martin Jay, "Scopic Regimes of Modernity," in Force Fields: Between Intellectual History and Cultural Critique (New York and London: Routledge, 1993), 114-133.

Norman Bryson, Vision and Painting: The Logic of the Gaze (New Haven: Yale University Press, 1983).

Jay, "Scopic Regimes," 123.

Ibid., 126.

Kramer, "Martin Jay," xiv.

Ibid., xv.

Šuvaković, Pojmovnik, 92-93. 
Bryson, Norman. Vision and Painting: The Logic of the Gaze. New Haven: Yale University Press, 1983.

Eagleton, Terry. Ideology: An Introduction. London and New York: Verso, 1991.

Jay, Martin. "Scopic Regimes of Modernity." In Force Fields: Between Intellectual History and Cultural Critique, 114-133. New York and London: Routledge, 1993.

Jay, Martin. Downcast Eyes: The Denigration of Vision in Twentieth-century French Thought. Berkeley: University of California Press, 1993.

Jay, Martin. The Dialectical Imagination: A History of the Frankfurt School and the Institute of Social Research, 1923-1950. London: Heinemann, 1973.

Kramer, Lloyd. "Martin Jay and the Dialectics of Intelectual History." In The Modernist Imagination: Intellectual History and Critical Theory. eds. Warren Breckman et al., xii-xiv. New York: Berghahn Books, 2011.

Marx, Karl and Frederick Engels. The German Ideology. New York: International Publishers, 1970

Solomon, Maynard. "General Introduction: Karl Marx and Friedrich Engels." In Marxism and Art: Essays Classic and Contemporary, ed. Maynard Solomon, 3-21. Detroit: Wayne State University Press, 1974.

Šuvaković, Miško. Pojmovnik teorije umetnosti. A Lexicon of Art Theory; Belgrade: Orion Art, 2011. 


\section{FENOMENOLOGIJE ARHITEKTURE}

\section{Vladimir Stevanović}

Ovaj tekst, u terminima analitičke estetike, sprovodi meta-diskusiju o načinima upotrebe termina i ideje fenomenologije u diskursu arhitektonske teorije. Pretpostavka je da se ne može sa sigurnošću i preciznošću tvrditi da teoretičari koji zastupaju fenomenološko mišljenje u kontekstu arhitekture ciljaju na iste teme i probleme. Ukoliko se u arhitektonskoj teoriji paralelno razvija više različitih fenomenologija, centralno pitanje postaje njihova međusobna kompatibilnost. Sprovedena analiza otvoriće mogućnost sagledavanja slučajeva u kojima se ove fenomenologije instrumentalizuju radi zagovaranja i promocije određenih stilsko-morfoloških arhitektonskih koncepata. Ovakve eksplicitne simpatije prema određenim arhitektima i stilovima govore ponajviše o afirmaciji sopstvenog ukusa i subjektivne preferencije arhitektonskih teoretičara fenomenologije. Prepoznavanje, ispitivanje i tumačenje kontradikcija u fenomenologijama arhitekture, a zatim njihovih instrumentalizacija, biće sprovedeno u relaciji sa širim teorijskim i društvenim kontekstom, počev od druge polovine XX veka. Ovaj period vremenski određuje diskusiju, jer se tada događa konstitutivna interakcija fenomenologije i arhitektonske teorije. U tom smislu, varijacije u fenomenologijama arhitekture sagledaće se u odnosu prema: 1) arhitektonskim teorijama i praksama visokog modernizma i postmodernizma poput pozitivizma, semiotike, apstrakcije i figuracije; 2) društveno-istorijskom kontekstu koji obuhvata dominaciju liberalnog kapitalizma, konzumerizam, posledice tehnološkog progresa, masovnu kulturu i populizam, kao i medijsku hiperprodukciju.

KLJUČNE REČI: FENOMENOLOGIJA ARHITEKTURE, DUH MESTA, TELO, POETSKA IMAGINACIJA, TAKTILNO ISKUSTVO

\section{MATERIJALISTČKA ISTORIJA IDEJA I STUDIJA ARHITEKTURE I URBANIZMA: SLUČAJ MARTINA DŽEJA}

\section{Nikola Dedić}

Istorija ideja je pod-disciplina istorije koja se bavi opisom I tumačenjem kreativnog rada mislilaca i umetnika iz prošlosti. Martin Džej, kao centralni aspekt svog teoretskog rada ističe dve Marksističke teze: 1. Ideje imaju, kao proizvod intelektualnog rada, svoje sopstvene materijalne osnove: to znači da je društvena stvarnost određena tim proizvodima isto toliko koliko i ekonomijom - na taj način, materijalistička istorija ideja je konstituisana na prelasku sa analize ekonomije (osnove) na analizu kulture (nadgradnja). 2. Ideje su povezane sa društvenim praksama: ideje unutar jednog društva nisu odvojene od materijalne stvarnosti, već one aktivno oblikuju društvene odnose, tj. psotoji veza između intelektualnog rada i političkih uslova života u datom istorijskom društvu. Ovaj rad ispituje vezu koju je Džej uspostavio između istorije ideja i istorije arhitekture i urbanizma.

KLJUČNE REČI: ARHITEKTURA, ISTORIJA IDEJA, URBANIZAM, MATERIJALIZAM, MARKSIZAM 